\title{
Influence of fat level reduction in the drying of Italian salami
}

\author{
Bis-Souza, C. V. ; Pollonio, M.A.R. $^{\text {b }}$, Penna, A.L.P. ${ }^{\text {a }}$, Barretto, A. C. S. a $^{a^{*}}$ \\ ${ }^{a}$ Department of Food Technology and Enginneering. UNESP- São Paulo State University, São José \\ do Rio Preto, SP, Brazil. \\ B Department of Food technology, UNICAMP - University of Campinas, Campinas, SP, Brazil.
}

*E-mail of the corresponding author: andreasb@ibilce.unesp.br

\begin{abstract}
The aim of this study was to evaluate the influence of fat reduction in the drying process of Italian salami. Two Italian salami formulations: HFS (High Fat Sausage) with 20g/100g of pork back fat and LFS (Low Fat Sausage) with $11.2 \mathrm{~g} / 100 \mathrm{~g}$ of pork back fat were analyzed as water activity, weight loss, proximate composition and $\mathrm{pH}$. The evaluation times were 0,3 , 7, 10 and 13 days of drying.The reduction of more than $25 \%$ in the fat content of Italian salami affected the weight loss in the drying process, but did not affect the moisture, $\mathrm{pH}$ and water activity.
\end{abstract}

Keywords: Low-fat; fermented sausage; weight loss; healthier meat products; ripening time. 


\section{Introduction}

Currently, there is an increase in consumer demand for healthier food products that have low calorie and low fat content. Because of this trend, the meat product manufacturers are seeking to develop new formulations of tradicional products, reducing fat content and using fat substitut on the aim of producing healthier meat products [1].

The high fat content in fermented sausages contributes to the sensory characteristics, such as taste, texture, juiciness, mouthfeel, lubricity and appearance, and its reduction can directly affect the acceptability of the product [2, 3]. However, there is an association between excessive consumption of saturated fat and increased risk of heart disease and some cancers $[4,5]$.

The drying stage of the fermented sausage represents an important factor for determining the physicochemical and sensorial properties of the final product. The duration of the drying step of the sausage is related to the diameter. This stage of the process should always be performed at temperatures, between $12^{\circ} \mathrm{C}$ and $15^{\circ} \mathrm{C}$. The sausage can lose up to $40 \%$ of its weight during the drying and this loss must be gradual to avoid deformation of the final product [6].

Fat reduction in dry fermented sausages is one of the most difficult because the excessive reduction of fat can leads to harder products and can increase the weight loss. But according to Olivares et al [2], those defects can be avoided if appropriate processing and climatic conditions of the drying process are applied correctly. So, the aim of this study was to evaluate the influence of fat reduction level on the drying process of Italian type salami.

\section{Materials and Methods}

\subsection{Italian type Salami drying process}

The samples were manufactured in the Laboratory of Meat and Derivatives at the Faculty of Food Engineering, University of Campinas (São Paulo, Brazil). Two levels of pork back fat were added in the Italian type salami formulation: HFS (High Fat Sausage) with $20 \mathrm{~g} / 100 \mathrm{~g}$ of pork back fat added and $80 \mathrm{~g} / 100 \mathrm{~g}$ of lean pork / LFC (Low Fat Sausage) with $11.2 \mathrm{~g} / 100 \mathrm{~g}$ of pork back fat added and $88 \mathrm{~g} / 100 \mathrm{~g}$ of lean pork. The other ingredients of the formulation were: sucrose $(2 \mathrm{~g} / 100 \mathrm{~g})$, sodium chloride $(2.5 \mathrm{~g} / 100 \mathrm{~g})$, sodium erythorbate $(0.5 \mathrm{~g} / 100 \mathrm{~g})$, sodium nitrite $(0.015 \mathrm{~g} / 100 \mathrm{~g})$, sodium nitrate $(0.015 \mathrm{~g} / 100 \mathrm{~g})$, white pepper $(0.5 \mathrm{~g} / 100 \mathrm{~g})$, garlic $(0.2 \mathrm{~g} / 100 \mathrm{~g})$, nutmeg $(0.2 \mathrm{~g} / 100 \mathrm{~g})$ and a starter culture $(0.25 \mathrm{~g} / \mathrm{kg}$; SPX Floracarn, Chr Hansen).

All ingredients were mixed with the raw material using a blender for approximately 5 minutes. After, the treatments were stuffed in cellulose cases (diameter of $50 \mathrm{~mm}$ ) and they were cut into pieces $15 \mathrm{~cm}$ in length. For each treatment 25 pieces (approximately $250 \mathrm{~g}$ 
each) were made and each sample was soaked in a solution of potassium sorbate $(20 \%)$. The temperature ad relative humidity parameters $\left(\mathrm{T}{ }^{\circ} \mathrm{C} / \mathrm{RH} \%\right.$ ) were: $25{ }^{\circ} \mathrm{C} / 95 \%$ (first day), $24{ }^{\circ} \mathrm{C} / 93 \%$ (second day), $23{ }^{\circ} \mathrm{C} / 91 \%$ (third day), $22{ }^{\circ} \mathrm{C} / 89 \%$ (fourth day), $21{ }^{\circ} \mathrm{C} / 87 \%$ (fifth day), $20{ }^{\circ} \mathrm{C} / 85 \%$ (sixth day), $18{ }^{\circ} \mathrm{C} / 85 \%$ (seventh day), $15{ }^{\circ} \mathrm{C} / 75 \%$ (until the end of ripening process). The air velocity during all the process was $0.5 \mathrm{~m} / \mathrm{s}$. The processing was performed twice.

\subsection{Ripening analysis}

Water activity was measured in triplicate using Aqualab Decagon equipment (Decagon Devices Inc., Pullman, USA).

The moisture, ash and protein content quantification was performed according to AOAC [7]. Fat content was measured using the Bligh \& Dyer method [8]. This analysis was performed in triplicate.

The $\mathrm{pH}$ was measured using a digital $\mathrm{pH}$ meter with penetration probe, in triplicate, in the same piece of salami.

To calculate the weight loss, the same samples were weighed throughout the drying process and the loss was determined by the difference calculation between the initial weight and the final weight $(\mathrm{n}=5)$.

\subsection{Statistical analysis}

The data obtained were analyzed by analysis of variance (ANOVA), and the differences between the means of the results were evaluated by the Fisher test $(P \leq 0.05)$ at a significance level of 5\%. The software used was MiniTab 16.

\section{Results and discussion}

\subsection{Proximate composition}

The moisture content of Italian type salami was different between batches only after the drying process (Table 1). 
Table 1. Proximate composition of Italian type salami high fat content (HFS) and low fat content (LFS) after 0 and 13 days of dry process.

\begin{tabular}{|c|c|c|c|c|c|}
\hline Analysis & Days of drying & HFS & LFS & SEM ${ }^{1}$ & p value \\
\hline \multirow{2}{*}{$\begin{array}{c}\text { Moisture } \\
(\%)\end{array}$} & 0 & $65.17^{\mathrm{A}}$ & $64.13^{\mathrm{A}}$ & 0.245 & 0.066 \\
\hline & 13 & $32.20^{\mathrm{B}}$ & $39.10^{\mathrm{A}}$ & 0.770 & $0.012 *$ \\
\hline \multirow{2}{*}{ Fat (\%) } & 0 & $13.5^{\mathrm{A}}$ & $10.21^{\mathrm{B}}$ & 0.488 & $0.02 *$ \\
\hline & 13 & $30.44^{\mathrm{A}}$ & $22.80^{\mathrm{B}}$ & 0.772 & $0.01 *$ \\
\hline \multirow{2}{*}{$\operatorname{Ash}(\%)$} & 0 & $3.61^{\mathrm{A}}$ & $3.47^{\mathrm{A}}$ & 0.071 & 0.182 \\
\hline & 13 & $5.35^{\mathrm{A}}$ & $5.85^{\mathrm{A}}$ & 0.412 & 0.349 \\
\hline \multirow{2}{*}{$\begin{array}{c}\text { Protein } \\
(\%)\end{array}$} & 0 & $15.56^{\mathrm{B}}$ & $18.60^{\mathrm{A}}$ & 0.352 & $0.013 *$ \\
\hline & 13 & $26.14^{\mathrm{A}}$ & $28.94^{\mathrm{A}}$ & 0.956 & 0.075 \\
\hline
\end{tabular}

${ }^{\mathrm{AB}}$ Different letters in the same line differ significantly $(\mathrm{P}<0.05)$ by the Fisher's test. *Significant. ${ }^{1}$ SEM: Standart error of the mean.

LFS had higher moisture content because of the fat reduction. Similar results were reported by Olivares et al [2] that manufacture dry sausage using different pork back fat content and the lowest (13.2\%) had the highest moisture at the end of the dryng process.

The results for ash and protein did not show differences at the end of the drying process. The reduction of fat level achieved was approximately $25 \%$. So, it is possible to classify this product as an Italian type Salami with reduced saturated fat content (light), according to the corresponding legislation [9].

\subsection{Ripening analysis}

The results for the water acttivity, $\mathrm{pH}$ and weight loss during the drying proceso of salami type Italian are presented in Figure 1. 


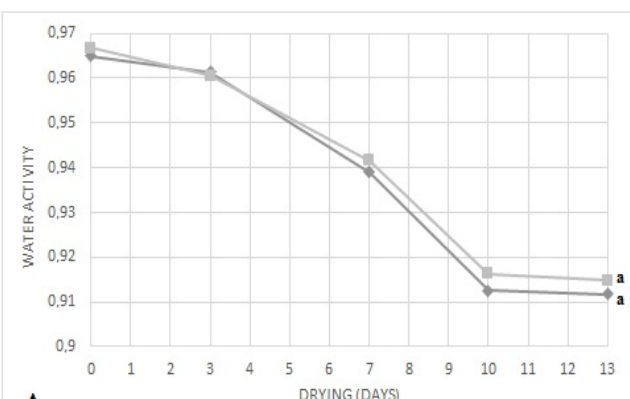

A

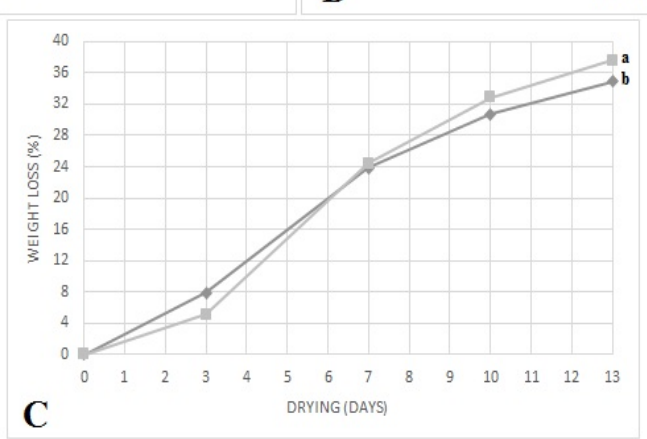

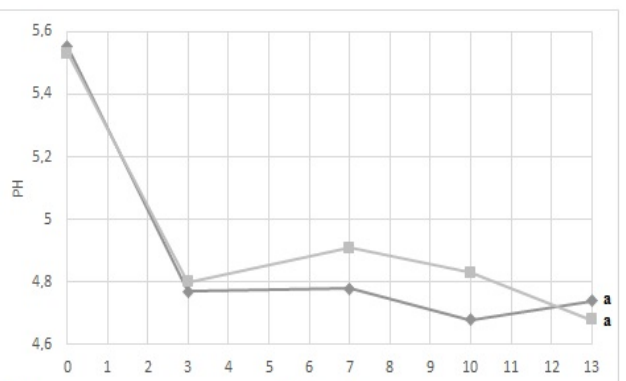

B DRYING (DAYS)

\section{Fig. 1. Evolution of water actitvy (A), pH (B) and weight loss (C) during the drying process of Italian type salami.}

${ }^{a b}$ Different letters in the graphic differ significantly $(\mathrm{P}<0.05)$ by the Fisher's test

The water activity (Fig.1A) of the treatments was reduced during processing (13 days), starting at 0.96 and reducing to 0.9. The high fat sausage (HFS) didn't show difference wáter activity from the low fat sausage (LFS) at the end of the drying processing. So the reduction in the pork fat of Italian type salami did not affect this technological parameter. This result is in agreement with Fonseca et al [10] that reported that the reduction in fat content $(10 \%, 20 \%$ and $30 \%$ fat $)$ in fermented dry salsichon had no significant effect on the water activity of the final product.

The initial $\mathrm{pH}$ (Fig.1B) of the batch was 5.6. After 3 days of processing, the $\mathrm{pH}$ value was near 4.6 for all treatments, indicating that micro-organisms present in the fermenting starter culture produced lactic acid from the sugars present in the formulation, reducing the $\mathrm{pH}$. Othes authors also reported a significant reduction of $\mathrm{pH}$ from day 0 to day 3 in the production of fermented sausage $[11,12]$.

To ensure the loss of water during the drying process, the $\mathrm{pH}$ should reach values close to the isoelectric point of the meat $(\mathrm{pH}$ 5.0). According to Price and Schiweigert [13] acidification contributes to the texture of the product, as well as in the formation of 
aromatic compounds and the typical salami flavor. This rapid drop in $\mathrm{pH}$ value, close to 4.6 ensures product stability and provides microbiological protection against gram negative bacteria. The reduction in the pork fat content did not affect the $\mathrm{pH}$ value during the drying of the fermented sausage.

HFS showed the lowest ( $p>0.05$ ) weight loss (Fig.1.C) (\%) compared to the other treatments (LFS), showing that fat level may influence yield. This result is in agreement with the results presented by Ham et al [14], who observed that the fermented salami with fat reduction had the lowest yield when compared to the control treatment (with no reduction in fat content).

\section{Conclusions}

The reduction of $25 \%$ in the fat content of Italian type salami can be used to produce a healthier dry fermented meat product without affected the technological parametrs such as moisture, $\mathrm{pH}$ and water activity durind the drying process.

\section{References}

[1] Menegas, L. Z.; Pimentel, T. C.; Garcia, S.; Prudencio, S. H. Dry-fermented chicken sausage produced with inulin and corn oil: Physicochemical, microbiological, and textural characteristics and acceptability during storage. Meat Science 2014, 93 (3), 501-506.

[2] Olivares, A.; Nnavarro, J. L.; Salvados, A.; Flores, M. Sensory acceptability of slow fermented sausages based on fat content and ripening time. Meat Science 2010, 86 (2), 251-257.

[3] Lorenzo, J. M.; Franco, D. Fat effect on physico-chemical, microbial and textural changes trough the manufactured of dry-cured foal sausages Lipolysis, proteolysis and sensory properties. Meat science, 2012, 92 (4), 704-714.

[4] Afshari, R.; Hosseini, H.; Mousavi Khaneghah, A.; Khaksar, R. Physico-chemical properties of functional low-fat beef burgers: Fatty acid profile modification. LWT Food Science and Technology 2017, 78(1), 325-331

[5] Han, M.; Bertram, H. C. Designing healthier comminuted meat products: Effect of dietary fibers on water distribution and texture of a fat-reduced meat model system. Meat Science 2017, 133(1), 159-165.

[6] Rech, R. A. Produção de salame tipo italiano com teor de sódio reduzido. Masters dissertation, Federal University of Santa Maria, 2010.

[7] AOAC. Official Methods of Analysis of AOAC International. Association of Official Analysis Chemists International, 2007. 
[8] Bligh, E. G.; Dyer, W. J. A rapid method of total lipid extraction and purification. Canadian Journal of Biochemistry and Physiology 1959, 37(8), 911-917.

[9] BRASIL, Ministry of Health. National Health Surveillance Agency (ANVISA) Resolution - RDC No. 54 of November 12, 2012. Technical Regulation on complementary Nutrition Information. http://portal.anvisa.gov.br/documents/\%2033880/2568070/rdc0054_12_11_2012.pdf/c 5ac23fd-974e-4f2c-9fbc-48f7e0a31864 (accessed Nov 08, 2017).

[10] Fonseca, S.; Gómez, M.; Dominguez, R.; Lorenzo, J. M. Physicochemical and sensory properties of Celta dry-ripened "salchichón” as affected by fat content. Grasas Y Aceites 2015, 66(1), e059.

[11] Bagdatli, A.; Kundakci, A. Optimization of compositional and structural properties in probiotic sausage production. Journal of Food Science and Technology 2016, 53( 3), 1679-1689.

[12] Park, W.; Kim, J. H.; Ju, M. G.; Hong, G. E.; Yeon, S. J. Enhancing quality characteristics of salami sausages formulated with whole buckheat flour during storage. Journal of Food Science and Technology 2017, 54 (2), 326, 332.

[13] Price, J. F.; Schweigert, B. S. Ciencia de la Carne y de los Productos Carnicos. 2. ed., Zaragoza: Acribia, 1994. 581 p.

[14] Ham, Y. K.; Hwang, K. E.; Kim, H. W.; Song, D. H.; Kim, Y. J.; Choi, Y. S.; Kim, C. J. Effects of fat replacement with a mixture of collagen and dietary fibre on small calibre fermented sausages. International Journal of Food Science and Technology 2016, 51(1), 96-104. 